\title{
NUTRITIONAL PROFILE OF PATIENTS IN A MULTIDISCIPLINARY TREATMENT PROGRAM FOR SEVERE OBESITY AND PREOPERATIVE BARIATRIC SURGERY
}

Perfil nutricional de pacientes em programa multidisciplinar de tratamento da obesidade grave e em pré-operatório de cirurgia bariátrica

Fernanda Cristina Carvalho Mattos MAGNO ${ }^{1,2}$, Monique Silveira da SILVA ${ }^{2}$, Larissa COHEN ${ }^{1}$

Luciana d'Abreu SARMENTO' ${ }^{1}$ Eliane Lopes ROSADO ${ }^{1,2}$, João Régis Ivar CARNEIRO

From ${ }^{1}$ Hospital Universitário Clementino Fraga Filho da Universidade Federal do Rio de Janeiro e 2 Universidade Federal do Rio de Janeiro ('University Hospital Clementino Fraga Filho of the University of Rio de Janeiro and ${ }^{2}$ Federal University of Rio de Janeiro), Rio de Janeiro, RJ, Brazil.
HEADINGS - Bariatric surgery. Obesity. Nutritional assessment.
ABSTRACT - Background: Along with the augmentation in obesity rates in recent years, the demand for bariatric surgery has startlingly increased. Nutritional counseling in the preoperative period is very important because it contributes to higher success rate in the post-operative period. Aim: To assess the nutritional status of patients in a multidisciplinary program for the treatment of severe obesity and pre-operatively for bariatric surgery, characterizing the consumption of healthy nutrients. Methods: A retrospective analysis of 30 patients was conducted. Personal information, anthropometric data and dietary assessment by 24-hour food record were collected. The analysis of energy intake was performed in Dietpro 5.1 Professional ${ }^{\circledR}$ program. The statistical treatment of the caloric intake was performed by an ANOVA test with Bonferroni's post hoc and for anthropometric data the paired t test was used. Results: From the total, $73 \%$ of the patients were women and $27 \%$ male, mean age was $48.4+12.9$ and $49.8+8.1$, respectively. A lower weight in the $5^{\text {th }}$ appointment was observed when compared with the $1^{\text {st }}$ one. There was a reduction in caloric intake in the $2^{\text {nd }}, 3^{\text {rd }}$, $4^{\text {th }}$ and $5^{\text {th }}$ appointments when compared with the $1^{\text {st }}$. It was observed that in the $5^{\text {th }}$ appointment more than $50 \%$ of the patients underwent six meals a day. There was an increase in the consumption of fruit along the appointments and $72.2 \%$ of patients consumed $1-2$ servings of fruit a day. Vegetables intake was high in all appointments in the pre-operative period and, although low, the whole grain products consumption has increased during the pre-operative period achieving $30 \%$ of the study population. Conclusion - There was a decrease in body weight, a trend in the decrease of the body mass index and waist circumference and quantitative and qualitative improvement of food consumption.

\section{Correspondence:}

Fernanda Cristina Carvalho Mattos Magno

E-mail: fernandamattos.nut@gmail.com

Financial source: none

Conflicts of interest: none

Received for publication: 10/12/2013 Accepted for publication: 25/03/2014
DESCRITORES - Cirurgia bariátrica. Obesidade. Avaliação nutricional.
RESUMO - Racional: Com o avanço da obesidade nos últimos anos, a procura pela cirurgia bariátrica tem aumentado de forma alarmante. O aconselhamento nutricional no período pré-operatório é de grande importância, pois contribui para maior taxa de sucesso no pós-operatório. Objetivo: Avaliar o perfil nutricional dos pacientes inseridos em um programa multidisciplinar para o tratamento da obesidade grave e em pré-operatório de cirurgia bariátrica, caracterizando o consumo de nutrientes saudáveis. Métodos - Foi realizada análise retrospectiva de 30 pacientes sendo coletadas informações pessoais, antropométricas e dietéticas por meio de recordatórios de 24 horas. A análise da ingestão energética foi realizada no programa Dietpro 5.1 Profissional ${ }^{\circledR}$. O tratamento estatístico do consumo calórico foi realizado pelo teste ANOVA com post hoc por Bonferroni e para os dados antropométricos foi utilizado o teste t pareado. Resultados: Do total dos pacientes $73 \%$ eram mulheres e $27 \%$ homens, com idade de $48,4 \pm 12,9$ e $49,8 \pm 8,1$, respectivamente. Foi observado menor peso na $5^{\mathrm{a}}$ consulta quando comparado com a $1^{\text {a }}$. Houve diminuição no consumo calórico nas $2^{a}, 3^{a}, 4^{a}$ e $5^{a}$ consultas quando comparadas com a $1^{a}$. Observou-se que na $5^{a}$ consulta mais de $50 \%$ dos pacientes realizavam seis refeições ao dia. Houve aumento no consumo de frutas ao longo das consultas chegando a $72,2 \%$ dos pacientes que consumiam de uma a duas porções de frutas ao dia. A ingestão de verduras e legumes era elevada em todas as consultas no período préoperatório e o consumo de produtos integrais, apesar de baixo, aumentou ao longo do período pré-operatório, alcançando $30 \%$ da população ao final do estudo. Conclusão: Houve diminuição do peso corporal, tendência na redução do IMC e circunferência do abdome e melhora quantitativa e qualitativa do consumo alimentar da população estudada.

\section{INTRODUCTION}

$\mathrm{O}$ besity is a chronic and heterogeneous endocrine-metabolic disease and its multifactorial causes may be related to hyperphagia and improper eating habits, sedentary lifestyle, genetic, metabolic, sociocultural and psychosocial factors ${ }^{9,10}$. The World Health Organization considers obesity as one of the most worrisome public health problems, due to the increase of its prevalence in recent decades and the serious consequences that could entail, being considered the most important nutritional disorder in developed and undeveloped countries ${ }^{25}$.

The dietary pattern associated to obesity and other chronic diseases is essentially characterized by insufficient consumption of fruits, vegetables, greens and by excessive intake of high energy density foods as well as those rich in fats, sugars and salt. The World Health Organization estimates that approximately 
2.7 million deaths per year worldwide may be linked to inadequate consumption of fruits, vegetables and greens, constituting one of the ten central factors in determining the global load of diseases ${ }^{7}$. In Brazil, the household availability of fruits, vegetables and greens, based on data from the Survey of Family Budgets for 2008-2009, was estimated at $2.3 \%$ of total recommended calorie needs. This availability remains way below the optimal level in all regions and all economic strata of the population ${ }^{12}$.

Along with the increase in morbid obesity registered in recent years, the demand for bariatric surgery grew up in Brazilian territory, having been conducted 16,000 procedures in 2003 and 60,000 in 2010 ${ }^{18}$.

Preoperative nutritional counseling contributes to a higher rate of post-operative success, and aims to promote initial weight loss, strengthen the patient's perception that weight loss is possible when the energy balance becomes negative, identify dietary mistakes and eating disorders, report significant changes the patient will undergone, start feeding pattern adjustments, promote real expectations of weight loss, prepare the patient for new feeding habits during postoperative period and check the patient's potential for a successful surgery ${ }^{1,8,20}$. Such followup is critical to reduce the risks associated to the surgical treatment and improve the postoperative results ${ }^{24}$.

The aim of this study was to evaluate the nutritional profile of the patients included into a multidisciplinary program for the treatment of severe obesity and bariatric surgery pre-op, featuring consumption of healthy nutrients.

\section{METHODS}

The present study was conducted at Hospital Universitário Clementino Fraga Filho, Rio de Janeiro, RJ, Brazil, where social information, food intake records and anthropometric data of the patients were obtained from medical records of the Bariatric Surgery Program. The study was approved by the Research Ethics Committee of the Hospital Universitário Clementino Fraga Filho, under Protocol 12-140.

Adult patients from both genders were selected and included in the program in preoperative stage. From an initial sample of 39 patients, those below the age of 18 years (3), and pregnant women (4) who had acute inflammatory processes in the course of the study (2) were excluded.

A retrospective analysis of data from 30 patients was conducted and the following anthropometrical variables were evaluated: height, weight and abdominal circumference preoperatively. For calculation of body mass index (BMI) the following formula was used: weight $(\mathrm{kg})$ divided by height $(\mathrm{m})$ squared $^{3}$.

Body weight and height were measured according to Gibson $^{10}$, using a digital scale (Welmy $\left.{ }^{\circledR}\right)$, with a maximum capacity of $300 \mathrm{~kg}$ divided by $50 \mathrm{~g}$ and a $0.1 \mathrm{~cm}$ scale stadiometer. Patients were weighted with minimum clothing and barefoot. For evaluation of abdominal circumference measurement was performed with an inelastic tape of $2.0 \mathrm{~m}$ length from Sanny ${ }^{\circledR}$ with scale in centimeters, according to the recommendations of the World Health Organization ${ }^{16}$.

For the evaluation of the caloric intake during the 24 hours recall it was used Dietpro 5.1 Professional ${ }^{\circledR}$.

Descriptive analysis of qualitative data was conducted. The quantitative variables were analyzed as mean and standard deviation. Data normality test was conducted using the Kolmogorov-Smirnov method (DallalWilkinson-Lilliefor for $p$ value). Calorie intake data from the preoperative consultations were analyzed by ANOVA with post hoc by Bonferroni. Paired t-test was conducted for anthropometric data obtained between the first and last visit. A two-tailed $p$ value of $<0.05$ was considered significant. Data were analyzed using Statistical Package for the Social Sciences program, version 16.0 for Windows ${ }^{23}$.

\section{RESULTS}

Evaluated patient characteristics are shown on Table 1. Of the total of 30 patients followed up, $73 \%(n=22)$ were women and $27 \%(n=8)$ were men with an average age of $38,4 \pm 12,9$ and $39,8 \pm 8,1$ years, respectively.

TABLE 1 - Characteristics of studied population

\begin{tabular}{|c|c|}
\hline Gender & $\% \quad(n)$ \\
\hline Female & $73 \quad(22)$ \\
\hline Male & 27 (8) \\
\hline Education Level & $\% \quad(n)$ \\
\hline Primary & $40 \quad(12)$ \\
\hline Secondary & $46 \quad(14)$ \\
\hline Bachelor's or equivalent & 14 (4) \\
\hline Comorbidities & $\% \quad(n)$ \\
\hline Diabetes mellitus type 2 & $40 \quad(12)$ \\
\hline Hypertension & $74 \quad(22)$ \\
\hline Dyslipidemia & 34 (10) \\
\hline $\mathrm{BMI} \mathrm{kg} / \mathrm{m}^{2}$ & $\% \quad(n)$ \\
\hline $30-34,9$ & $10 \quad(3)$ \\
\hline $35-39,9$ & $44 \quad(13)$ \\
\hline $40-49,9$ & $34 \quad(10)$ \\
\hline $50-60$ & $12 \quad(4)$ \\
\hline Family history of obesity & $\% \quad(n)$ \\
\hline Yes & $50 \quad(15)$ \\
\hline No & $50 \quad(15)$ \\
\hline Begining of obesity & $\% \quad(n)$ \\
\hline Childhood & $3,3 \quad(1)$ \\
\hline Adolescence & $33,3(10)$ \\
\hline Adulthood & $63,3(19)$ \\
\hline
\end{tabular}

BMI=body mass index; \%=percentage; $n=$ patient number

The anthropometric assessment showed lower weight on $5^{\text {th }}$ appointment compared to the initial consultation. There was no difference between BMI and abdomen circumference along the queries (Table 2).

TABLE 2 - Population anthropometric data expressed in means and standard deviation

\begin{tabular}{|c|c|c|c|}
\hline Variable & Weight $(\mathrm{kg})$ & $\mathrm{BMI}\left(\mathrm{kg} / \mathrm{m}^{2}\right)$ & $\mathrm{AC}(\mathrm{cm})$ \\
\hline 1st Appointment & $133,8 \mathrm{~kg} \pm 32,3^{*}$ & $50,8 \pm 14,5$ & $128,8 \pm 23,6$ \\
\hline 2nd Appointment & $133,7 \mathrm{~kg} \pm 39,1$ & $51,4 \pm 16,8$ & $127,7 \pm 30,6$ \\
\hline 3rd Appointment & $132,6 \mathrm{~kg} \pm 42,2$ & $50,9 \pm 18,3$ & $125,5 \pm 18,7$ \\
\hline 4th Appointment & $136,2 \mathrm{~kg} \pm 29,7$ & $51,6 \pm 12,1$ & $131,3 \pm 23,2$ \\
\hline 5th Appointment & $129,7 \mathrm{~kg} \pm 12,8^{*}$ & $49,5 \pm 2,9$ & $128,5 \pm 16,4$ \\
\hline
\end{tabular}

$\mathrm{BMI}=$ body mass index; $\mathrm{Kg}=$ kilograms; $\mathrm{Kg} / \mathrm{m}^{2}=$ kilogram per square meter $\mathrm{AC}=$ abdomen circumference; $\mathrm{HQ}=$ hip circumference; $\mathrm{cm}=$ centimeters *Unpaired t-Test $(p<0,05)$ comparing $1^{\text {st }}$ and $2^{\text {nd }}$ appointments during pre-op

There was a decrease in caloric intake on $2^{\text {nd }}, 3^{\text {rd }}, 4^{\text {th }}$ and $5^{\text {th }}$ appointments in comparison with the first appointment. There was also a decrease in caloric intake on $3^{\text {rd }}, 4^{\text {th }}$ and $5^{\text {th }}$ queries 
compared to the second. No differences were found between the caloric intake from the third appointment (Table 3).

TABELA 3 - Caloric intake evaluation (means and standard deviation)

\begin{tabular}{|c|c|}
\hline Appointments & Caloric intake (Kcal) \\
\hline 1st Appointment & $3658 \pm 673 \mathrm{bcd}$ \\
\hline 2nd Appointment & $2680 \pm 309^{\mathrm{a}}$ \\
\hline 3rd Appointment & $2040 \pm 194^{\mathrm{ab}}$ \\
\hline 4th Appointment & $2220 \pm 220^{\mathrm{ab}}$ \\
\hline 5th Appointment & $2170 \pm 199^{\mathrm{ab}}$ \\
\hline
\end{tabular}

Kcal=kilolocalorie; ANOVA test with post hoc Bonferroni with $5 \%$ probability, where: ${ }^{a} p<0.05$ vs. $1^{\text {st }}$ appointment, ${ }^{b} p<0.05$ vs $2^{\text {nd }}$ appointment, ${ }^{c} p<0.05$ vs $3^{\text {rd }}$ appointment, ${ }^{d} p<0.05$ vs $4^{\text {th }}$ appointment

With respect to the number of daily meals, it was observed in the first appointment a diverse distribution of patients who divided meals from two to six times a day. From the second appointment on, it was observed that all patients divided meals at least three times a day. In the $3^{\text {rd }}$ and $5^{\text {th }}$ appointments patients divided meals in four times or more a day and on $5^{\text {th }}$ appointment more than $50 \%$ of patients divided their meals six times a day (Figure 1)



FIGURE 1 - Patient distribution along appointments vs meals per day

Figure 2 presents data on the consumption of fruit along the preoperative consultation. Almost half of the population $(46.7 \%)$ of the study didn't consumed any kind of fruit in the first appointment. It was registered an increase of patients who consume one to two servings of fruits a day along the queries reaching $72.2 \%$ of the study population.

High vegetable consumption was observed in all preoperative queries. As for wholegrain products, despite the low consumption, an increase was registered along the preoperative period, reaching $30 \%$ of the study population (Table 4).

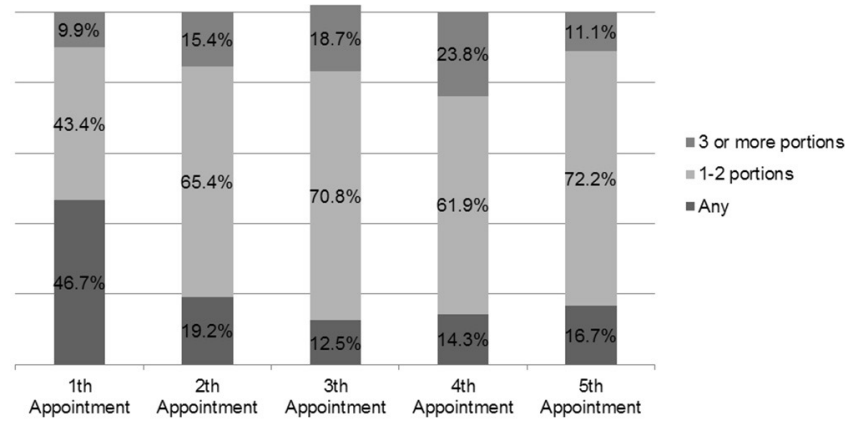

FIGURE 2 - Patient distribution vs fruit consumption along appointments

DISCUSSION

The preoperative period consists of a set of behaviors and care procedures under the responsibility of a multidisciplinary team in order to prepare the patients psychologically, medically and nutritionally for surgery and postoperative period. Knowing the patient's nutritional profile before surgery helps the nutritionist to assess the degree of knowledge they have about what they eat, as well as their eating habits and of their families, as well as characteristics related to social conviviality and understanding about the changes that will occur after the completion of surgery. The knowledge and the clarification of most or all of these factors, even in the preoperative period, are of great importance for changes in their lifestyle, leading to greater likelihood of success in the treatment and control of obesity.

According to data from the Household Budget Survey, conducted by the Brazilian Institute of Geography and Statistics, in 34 years, elapsed between 1974-1975 and 2008-2009, there was an increase in the prevalence of obesity (BMI greater than or equal to $30 \mathrm{~kg} / \mathrm{m}^{2}$ ) of more than four times in men (from $2.8 \%$ to $12.4 \%)$ and more than two times in women $(8.0 \% \text { to } 16.9 \%)^{12,13}$.

According to a systematic review where 134 studies were analyzed totaling 19,338 patients with an average age of 39 years, it was observed a distribution of obesity in men and women of $19.4 \%$ and $72.6 \%$, respectively. In this same study it was demonstrated the presence of diabetes mellitus type 2 in $15.3 \%$, hypertension in $35.4 \%$ and dyslipidemia in $35.6 \%$ of patients 6 .

The findings in the present study regarding patients distribution by age and sex and the presence of comorbidities such as diabetes mellitus and dyslipidemia corroborates data found in the literature. However, this study reported that $74 \%$ of the population showed systemic arterial hypertension. The presence of one or more co-morbidities is common in obese patients, which could explain the high incidence of hypertension. Another explanation may be that patients in this study joined a program that works in a tertiary hospital.

A minor reduction of $5 \%$ to $10 \%$ of body weight can result in the improvement of various clinical indicators of an obese

TABLE 4 - Patient distribution according to vegetable, greens and wholegrain product consumption along appointments

\begin{tabular}{|c|c|c|c|c|c|}
\hline \multicolumn{6}{|c|}{ Vegetable consumption } \\
\hline Consumption/Appointments & $1^{\text {st }}$ Appointment & $2^{\text {nd }}$ Appointment & $3^{\text {rd }}$ Appointment & $4^{\text {th }}$ Appointment & $5^{\text {th }}$ Appointment \\
\hline Yes & $80 \%$ & $61 \%$ & $100 \%$ & $80 \%$ & $90 \%$ \\
\hline No & $20 \%$ & $39 \%$ & -- & $20 \%$ & $10 \%$ \\
\hline \multicolumn{6}{|c|}{ Greens consumption } \\
\hline Consumption/Appointments & $1^{\text {st }}$ Appointment & $2^{\text {nd }}$ Appointment & $3^{\text {rd }}$ Appointment & $4^{\text {th }}$ Appointment & $5^{\text {th }}$ Appointment \\
\hline Yes & $60 \%$ & $82 \%$ & $91 \%$ & $90 \%$ & $94 \%$ \\
\hline No & $40 \%$ & $18 \%$ & $9 \%$ & $10 \%$ & $6 \%$ \\
\hline \multicolumn{6}{|c|}{ Wholegrain consumption } \\
\hline Consumption/Appointments & $1^{\text {st }}$ Appointment & $2^{\text {nd }}$ Appointment & $3^{\text {rd }}$ Appointment & $4^{\text {th }}$ Appointment & $5^{\text {th }}$ Appointment \\
\hline Yes & $3 \%$ & $3 \%$ & $9 \%$ & $24 \%$ & $30 \%$ \\
\hline No & $97 \%$ & $97 \%$ & $91 \%$ & $76 \%$ & $70 \%$ \\
\hline
\end{tabular}


patient, which may reduce the risk of deaths in preoperative period of bariatric surgery ${ }^{15}$. In this study there was a significant decrease in body weight in the $5^{\text {th }}$ appointment when compared to the first one. However, this loss was less than $5 \%$. The impact in the control of comorbidities was not assessed in this study. Perhaps a most significant weight loss could be observed in a longer period of observation.

The perimeter of the abdomen circumference was assessed. However, in individuals with a BMI equal to or greater than 35 $\mathrm{kg} / \mathrm{m}^{2}$, the perimeter of the abdomen was measured through the greater abdominal extension, which can match the umbilical scar, purely for the purpose of monitoring weight evolution ${ }^{14}$.

Studies reporting the evolution of caloric intake in the preoperative period are scarce, noting that most of them reports postoperative evolution. Bortoluzzo ${ }^{2}$ found a $2038.06 \pm 820.89$ Kcal consumption in 18 patients of both sexes in the preoperative; Rockenbach et al. ${ }^{17}$ found a consumption of $2248.8 \pm 1166.9$ $\mathrm{Kcal}$ in 20 women; Bregion et al. ${ }^{5}$ found a consumption of $2343.04 \pm 708.46 \mathrm{Kcal}$ in 34 patients of both sexes; Santos et al. ${ }^{21}$ found a consumption of $1972.9 \pm 834.0 \mathrm{Kcal}$ in 26 women and Horvath et al..$^{11}$ found a consumption of of $2896.71 \pm 1134.89 \mathrm{Kcal}$ in 60 patients of both genders.

Comparing the characteristics of energy consumption in the initial and following appointments, patients showed a significant decrease in caloric intake during the first two appointments in comparison with the following visits. It was observed that the initial caloric intake was higher than that reported in previous studies. However, throughout the consultations, caloric intake was reduced, reaching $2170 \pm 199 \mathrm{kcal}$ in the last appointment, which is in accordance with the values presented in the literature.

The Ministry of Health's Food Guide for the Brazilian population recommends that: "To ensure good health, eat at least three meals a day (breakfast, lunch and dinner), interspersed by small snacks" ${ }^{\prime \prime}$. According to this recommendation the ideal fractionation of meals would be six times a day. This same booklet also recommends daily consumption of at least three servings of fruits and three servings of greens and vegetables, stressing the importance of diversifying the consumption of these foods in meals over the course of the week ${ }^{4}$.

A study conducted by Souza, et al. ${ }^{22}$, showed that a nutritional monitoring journal has great influence on eating habits and behavioral changes of patients, with large impact on the number of meals taken throughout the day, leading to the consumption of three or more meals, as well as an increased consumption of fruits and vegetables.

In this study it was possible to observe that the dietary pattern has changed significantly. Many patients started to split daily meals, consume fewer calories and increase the intake of fruits and wholegrain products. Even with the modification of eating habits it was not observed a significant weight loss. However, it should be emphasized that one cannot assign only dietary factors as the sole cause of obesity, being important to consider that it is a chronic disease with multifactorial causes.

The findings of this study demonstrate not only the importance of nutritional intervention in the run-up to the operation, as well as the fact that it is possible to promote changes in dietary habits, which should be incorporated in lifestyle, with or without surgical intervention. Further studies with multidisciplinary teams are needed still in the preoperative monitoring period in order to improve the health professional conduct according to the profile of the patients of bariatric surgery programs.

\section{CONCLUSION}

There was a decrease of body weight, trend in the reduction of BMI and also in abdomen circumference, and a significant improvement of quantitative and qualitative dietary consumption of the studied population.

\section{REFERENCES}

1. Bordalo LA, Teixeira TFS, Bressan J, Mourão DM. Cirurgia Bariátrica: Como e por que suplementar. Revista da Associação Médica Brasileira. 2011; 57(1): 113-120.

2. Bortoluzzo RF. Evolução nutricional e práticas alimentares de obesos mórbidos submetidos à cirurgia bariátrica em um hospital da rede pública [dissertação]. São Paulo: Universidade de São Paulo; 2005.

3. Brasil. Ministério da Saúde. Guia alimentar para a população brasileira: promovendo a alimentação saudável. Série A - Normas e Manuais Técnicos. Brasília, DF, 2006.

4. Brasil. Ministério da Saúde. Secretaria de Atenção à Saúde. Departamento de Atenção Básica. Obesidade. Brasília: Ministério da Saúde; 2006.

5. Bregion NO, Silva SA, Salvo VLMA. Estado Nutricional e Condição de Saúde de Pacientes nos Períodos pré e pós-operatório de cirurgia Bariátrica. Revista Brasileira de Ciências da Saúde. 2007; 5(14):31-41.

6. Buchwald $H$, Avidor $Y$, Braunwald E, Jensen MD, Pories W, Fahrbach $\mathrm{K}$ et al. Bariatric surgery. A systemic review and meta-analysis. JAMA. 2004; 292(14): 1724-1737.

7. Claro R, Carmo HCE, Machado FMS, Monteiro CA.. Renda, preço dos alimentos e participação de frutas e hortaliças na dieta. Revista Saúde Pública. 2007; 41(4): 557-564.

8. Cruz MRR, Morimoto IMI. Intervenção nutricional no tratamento cirúrgico da obesidade mórbida: resultados de um protocolo diferenciado. Revista de Nutrição. 2004; 17(2): 263-272.

9. Germano ACPL, Camelo CMBM, Batista FM, Carvalho NMA, Liberali $R$, Coutinho VF. Perfil Nutricional dos pacientes submetidos à cirurgia bariátrica e dos critérios adotados para encaminhamento em um hospital de João Pessoa, PB. Ensaios e Ciências Biológicas, Agrárias e da Saúde. 2011; 14(2): 43-59.

10. Gibson RS. Principles of nutritional dymatic. New York: Oxford, 1990.

11. Horvath JDC. Perfil nutricional, metabólico e presença de transtornos alimentares em obesos graves e sua adequação alimentar conforme DRI [dissertação]. Porto Alegre: Universidade Federal do Rio Grande do Sul. Porto Alegre; 2012.

12. InstitutoBrasileiro deGeografiaeEstatística. PesquisadeOrçamentos Familiares 2008-2009: Antropometria e estado nutricional de crianças adolescentes e adultos no Brasil. Instituto Brasileiro de Geografia e Estatística: Rio de Janeiro, 2010.

13. Instituto Brasileiro de Geografia e Estatística. Pesquisa de Orçamentos Familiares 2002-2003: análise da disponibilidade domiciliar de alimentos e do estado nutricional no Brasil. Instituto Brasileiro de Geografia e Estatística: Rio de Janeiro, 2004.

14. Lohman TG, Roche AF, Martorelli R. Anthropometric Standardization Reference Manual. Champaigne: Human Kinetics, 1991.

15. Lottenberg AMP. Tratamento dietético da obesidade. Einstein. 2006; 4(1): 23-28.

16. Organização Mundial de Saúde. Obesity-Presenting and managing the global epidemic. Report of a WHO consultation on obesity. Genebra, 2000.

17. Rockenbach KF. Cirurgia bariátrica: evolução nutricional no pósoperatório. [Monografia]. Cascavel. Faculdade Assis Gurgacz; 2006.

18. Santos LA. Avaliação Nutricional de pacientes obesos antes e seis meses após a cirurgia bariátrica [dissertação]. Minas Gerais: Universidade Federal de Minas Gerais; 2007,

19. Sarturi JB, Neves J, Peres KG. Obesidade em adultos: estudo de base populacional num município de pequeno porte no sul do Brasil em 2005. Ciências \& Saúde Coletiva. 2010; 15(1): 105-113

20. Segal A, Fandiño J. Indicações e contraindicações para realização das operações bariátricas. Revista Brasileira de Psiquiatria. 2002; 24(3): 68-72.

21. Sociedade Brasileira de Cirurgia Bariátrica e Metabólica. Disponível em: http://www.sbcb.org.br/laparoscopia.asp?menu=1. Acesso em: 17 de novembro de 2013.

22. Souza JMB, Castro MM, Maia EMC, Ribeiro NA, Almondes KM, Silva NG. Obesidade e tratamento: desafio comportamental e social. Revista Brasileira de Terapias Cognitivas. 2005; 1(1): 59-67.

23. Statistical Package for the Social Sciences. Advanced statistics 16.0. Chicago: SPSS Inc., 2007.

24. Vargas MA, Fernández NC, Serrano J. Preoperative weight loss in patients with indication of bariatric surgery: which is the best method? NutrciónHospitalária. 2011; 26(6): 1227-1230.

25. Wanderley EM, Ferreira VA. Obesidade: uma perspectiva plural. Ciência e Saúde Coletiva. 2010; 15(1): 185-194. 